\title{
A bibliometric analysis of a national Journal: The case of the Turkish Journal of Psychology
}

\author{
Engin Arik ${ }^{1,2 *}$ \\ ${ }^{1}$ Dogus University FEF Department of Psychology Acibadem, Kadikoy Istanbul 34722, Turkey, ${ }^{2}$ Purdue University IDIS Linguistics Program, \\ 1239 Beering Hall, West Lafayette, IN 47906, US
}

\begin{abstract}
What contributions do researchers in the social sciences and humanities in Turkey make to science internationally? In an attempt to answer this question, this study conducts a bibliometric analysis of the Turkish Journal of Psychology (Turk Psikoloji Dergisi [TPD]) as indexed in the Social Science Citation Index Multidisciplinary Psychology since 1995, volume 10, issue 35. Descriptive data showed that TPD published a total of 215 articles, about 11 per year, in Turkish (84.65\%) and English (15.35\%). On an average, an article was authored by 2 (2.01) authors and the article/unique author ratio was about 1:1 (.98). Apart from Turkey, authors were affiliated with the USA, Canada, The Netherlands, Australia, Cyprus, England, and Germany. Most of the publications were products of authors affiliated with universities in Ankara, Turkey. TPD was ranked 115 out of 126 journals in the category of Multidisciplinary Psychology in the Journal Citation Reports-Social Sciences Edition, with an impact factor of 0.214 in 2012 and a 5-year impact factor of 0.154. Aside from the most common words such as the, in, and so on, "Turkish" $(n=30)$, followed by "study" and "memory," were the most frequently used words in titles; "study," ( $n=325)$ "memory," $(n=206)$ and "between" $(n=201)$ were the most frequently used words in abstracts. On an average, articles had about five keywords, including about four keywords unique to the article. These findings suggest that TPD is an extremely local, but highly impactful journal publishing articles on very diverse topics from self to culture, and from memory to depression to scale development.
\end{abstract}

Keywords: Bibliometric analysis, Social Science Citation Index, Social Science Publications in Turkey, Turkish Journal of Psychology

\section{INTRODUCTION}

Citation indices offering bibliometric indicators about scientific publications are very important for storing, accessing, and disseminating information in previous and current scientific research. Publications accessible by databases have become very crucial not only for scientific productivity, quality of publication, and competition (inter) nationally, but also for job hunting, promotions, and

*Address for correspondence:

E-mail: enginarik@enginarik.com

\begin{tabular}{|l|l|}
\hline \multicolumn{2}{|c|}{ Access this article online } \\
\hline Quick Response Code: & Website: \\
\hline & www.jscires.org \\
& Dol: \\
\hline
\end{tabular}

respectability of researchers..$^{[1-5]}$ From this perspective, leading international journals, that is, highly respectable journals with high impact factors in a given field, may have more advantages than the local or national journals. Given that, how do national journals survive? What are the main bibliometric characteristics of national journals?

To answer these questions, in this study, I focus on the journal Turkish Journal of Psychology (Turk Psikoloji Dergisi [TPD]), published twice a year by the Turkish Psychological Association. I analyze it as it appears in the Social Science Citation Index (SSCI). The rationale behind the focus of this study was because TPD is one of the main ways for Turkish psychologists to contribute to the field of psychology as represented in SSCI. TPD is the only psychology journal indexed in SSCI with a Turkish address. This journal has published a total of 215 articles indexed in SSCI since 1995, of a total of 2152 articles indexed in psychology indices in SSCI with an address in Turkey. This 
result indicates that TPD carries about $10 \%$ of Turkish contributions to psychology as reflected in SSCI. TPD is also a very important journal for the Turkish science community, since it is one of the fourteen Turkish journals indexed in SSCI. ${ }^{[6]}$ In this study, I will show that TPD is an extremely local, but locally very important journal, which publishes articles on very diverse topics.

There are several databases, which are specific to psychology journals. For example, PsycINFO and PsycARTICLES are of high importance since they are run by the American Psychological Association (APA). Thomson Reuter's Web of Science (WoS) lists psychology in SSCI. For bibliometrics, SSCI is more important than the others because, according to Russ-Eft, ${ }^{[7]} \mathrm{SSCI}$ indexes timely published journals which have referee systems and higher impact factors than those not in SSCI. This might be misleading because publications, which are not in SSCI, may also provide significant contributions to the field. For example, one study ${ }^{[8]}$ investigated non-SSCI but highly cited publications in political science, economics, and psychology, and showed that $62 \%$ of those publications in psychology were books, almost all published in the USA and Europe. Nevertheless, analyzing bibliometric indicators from SSCI provides us a better picture of the quality of a journal.

Currently, SSCI has eleven subcategories of psychology: Psychology, Multidisciplinary Psychology, Clinical Psychology, Experimental Psychology, Developmental Psychology, Applied Psychology, Educational Psychology, Biological Psychology, Mathematical Psychology, and Psychoanalysis Psychology. A journal can be listed within one or more subcategories. Lluch ${ }^{[9]}$ showed that most of the journals were in Multidisciplinary Psychology $(n=102)$ and in Clinical Psychology $(n=83)$ in Thomson Reuters' Journal Citation Reports. TPD is also listed in Multidisciplinary Psychology.

Previous research indicates that there has been an increase in the number of psychology publications appearing in SSCI. One study ${ }^{[10]}$ showed that this increase has been observed in the psychology publications indexed in SSCI with addresses in Turkey, Iran, Greece, England, Germany, The Netherlands, and the USA in the last three decades. That study also showed that the total number of publications from Turkey were higher than those from Greece and Iran, but lower than those from England, Germany, The Netherlands, and the USA. The findings indicated that the ratio of psychology publications to all social science and humanities publications in SSCI was quite considerable in seven countries: on an average, Turkey (11.31\%), Iran (10.93\%), Greece (13.22\%), England (15.86\%), The Netherlands (24.90\%), Germany $(22.54 \%)$, and the USA (21.14\%).

Another study also provided evidence for this increase. Guilera, Barrios, and Gomez-Benito ${ }^{[1]}$ analyzed psychology publications in Science Citation Index-Expanded and SSCI databases until 2010, conducting a meta-analysis of previous findings on a specific topic. They found that there was an increase not only in the number of publications, but also authors per publication in psychology since the 1970s. They also found that there was an increase in international collaborations among authors since the 1990s. Of those publications, $57.52 \%$ were conducted in the USA; 7.41\% in Canada; 7.41\% in England; 6.09\% in The Netherlands; and 5.29\% in Germany.

This increase in the number of publications can also be observed in the increasing number of international collaborations. Kliegl and Bates ${ }^{[12]}$ studied 12 highly impactful journals published by the APA and the American Psychological Society, including Developmental Psychology, Journal of Experimental Psychology: General, Journal of Experimental Psychology: Human Perception and Performance, Journal of Experimental Psychology: Learning, Memory, and Cognition, Journal of Personality and Social Psychology, Psychology and Aging, Psychological Bulletin, Psychological Review, and Psychological Science. They found an increase in the number of publications with co-authors from various countries. They also showed that these collaboration patterns started in the 1970s and proceeded at an accelerated rate from the beginning of the 1990s.

There already exists considerable research on SSCI publications with their addresses listed in Turkey. Gulgoz et al. ${ }^{[13]}$ conducted a study in which they analyzed a total of 1916 SSCI publications from Turkey between 1970 and 1999, and showed that there was an increase in the number of publications in this period; however, this increase seemed to be slower than what was observed worldwide. They also showed that there was a decrease over the years in the number of citations that those articles received. One of the reasons for this, they argued, was that there were a limited number of collaborations among Turkish scholars and those abroad. Tonta and İlhan ${ }^{[14]}$ conducted research focusing on SSCI publications between 1985 and 1996. They found that there were a total of 887 publications listing an address in 
Turkey. In 1996, the ratio of the publications $(n=166)$ from Turkey to publications worldwide in SSCI was $0.14 \%$. What is interesting is that the majority of these publications were authored by researchers affiliated with only a few universities. In another study, Gossart and Ozman ${ }^{[15]}$ analyzed publications from Turkey indexed in SSCI and by the Turkish Academic Network and Information Center of the Scientific and Technological Research Council of Turkey. They found that some researchers in Turkey published only internationally and some only nationally. They also found that the scientific network was very limited among both universities and researchers.

There also exists an earlier study ${ }^{[16]}$ focused only on TPD which showed that this journal published most of its articles in Turkish, and that most were written by researchers affiliated with a few universities, such as Hacettepe University, Ankara University, and the Middle East Technical University. The citation patterns of the articles indicated that $69 \%$ of the cited references were given to studies published in TPD. In addition, although those articles received a total of 135 citations, the majority of them were not cited at all. Of the 135 citations, $35 \%$ were author self-citations and $41 \%$ were journal self-citations. This resulted in a low impact factor: In 2004, TPD was ranked 415 of 425 journals in JCR.

\section{METHODS}

In order to gather data on TPD, WoS was accessed at http://apps.webofknowledge.com/on October 10, 2013 through Purdue University Libraries. “TPD” was entered as a keyword in publication name. Timespan was adjusted to all years. After clicking the search button, results showed that there were 215 articles and 7 editorial materials. The results were refined by selecting articles in the document type. In the refined results, there were several categories. Of them, the WoS categories showed that TPD was categorized as a Psychology Multidisciplinary Journal. Under Research areas, only psychology was listed. After clicking authors then more options/ values, the first 100 authors and their number of publications were accessed. Since this result was limited to the first 100 authors only, the search was refined later by analyzing the information from the article entries. Source titles were TPD. There was no record under book series titles, conference titles, or funding agencies. By clicking on the sections on the left, and then more options/values, I also noted the publication years, the number of publications each year, the authors' affiliations (organizations-enhanced), the languages of publications, and the authors' countries/ territories. I then went back to the articles, selected all of them, then saved a record by clicking print records then selecting full record and cited references. The results page was then saved in pdf, html, and txt formats for further analysis. By doing this, I was able to access the following information for each article: Full title of the publication, author(s), source, times cited, cited references, abstract, accession number, document type, language, author keywords, keywords plus, reprint address, addresses, e-mail addresses, publisher, WoS categories, research areas, IDS Number: 783HL, ISSN: 1300-4433, 29-character long source abbreviation, iso source abbreviation, and source item page count. In my analysis, I focused on publication years and language, page count, author(s), and their countries and organizations, cited references and received citations, titles of the papers, their abstracts, and keywords.

In order to further analyze titles, abstracts, and keywords, I used a corpus linguistics software, AntConc. ${ }^{[17]}$ With this software, I counted the total number of words (tokens), word types, and phrasal patterns.

\section{RESULTS}

\section{Editors}

Even though, they were not listed in SSCI, TPD had an editor, ${ }^{[18]}$ three associate editors (O. C. Cirakoglu, D. Kokdemir, T. Ozkan), and an advisory board consisting of 70 people, all of which were Turkish and currently affiliated with a Turkish University. This finding provides supporting evidence to my claim that TPD is a very local journal.

\section{Publication Years}

Turk Psikoloji Dergisi normally published two issues per volume per year. On an average, TPD published about 11 (11.31) articles per year. Figure 1 gives the number of publications per year between 1995 and 2013.

\section{Page Count}

On an average, each article was 17 (16.71) pages long. The longest article was 39 pages, ${ }^{[19]}$ whereas the shortest article was 3 pages. ${ }^{[20]}$

\section{Language}

Of the 215 articles, $182(84.65 \%)$ were in Turkish and 33 were in English. 


\section{Author(s)}

Including repeated authors, there were a total of 434 authors of the various articles. This finding indicated that on average, each article had 2 (2.01) authors. The highest number of co-authors was 8 and the lowest was 1 . Results by AntConc showed that there were 211 different authors, suggesting that the article/author ratio was about 1 (.98). Only 14 authors were not of Turkish origin. N. Er authored the most articles, 8 , as a first author, and was followed by N. Sumer, who authored 6 articles. 141 scholars published only once. Figure 2 gives the ranking of authors who published most as a co-author.

\section{Countries}

In addition to Turkey (209), authors were affiliated with The USA (8), Canada (3), The Netherlands (2), Australia (1), Cyprus (1), England (1), and Germany (1). A closer examination of this finding showed that almost all of the articles had at least one Turkish author with the exception of Backs and Dobson, ${ }^{[21]}$ which was written by authors of non-Turkish origin. Apart from these two individuals, there were only seven co-authors of non-Turkish origin. This finding suggests that TPD remains entirely a national journal.

\section{Organizations}

The authors of the articles in TPD were affiliated with a variety of universities. Considering that there are currently 58 universities in Turkey which have psychology departments, with a total of 360 faculty members with a doctoral degree, this variation does not represent the majority of the universities. However, most of these departments were recently established. For example, there were only 10 psychology departments in 1996, whereas there were 22 in 2005 and 58 in 2013. Nevertheless, most of the

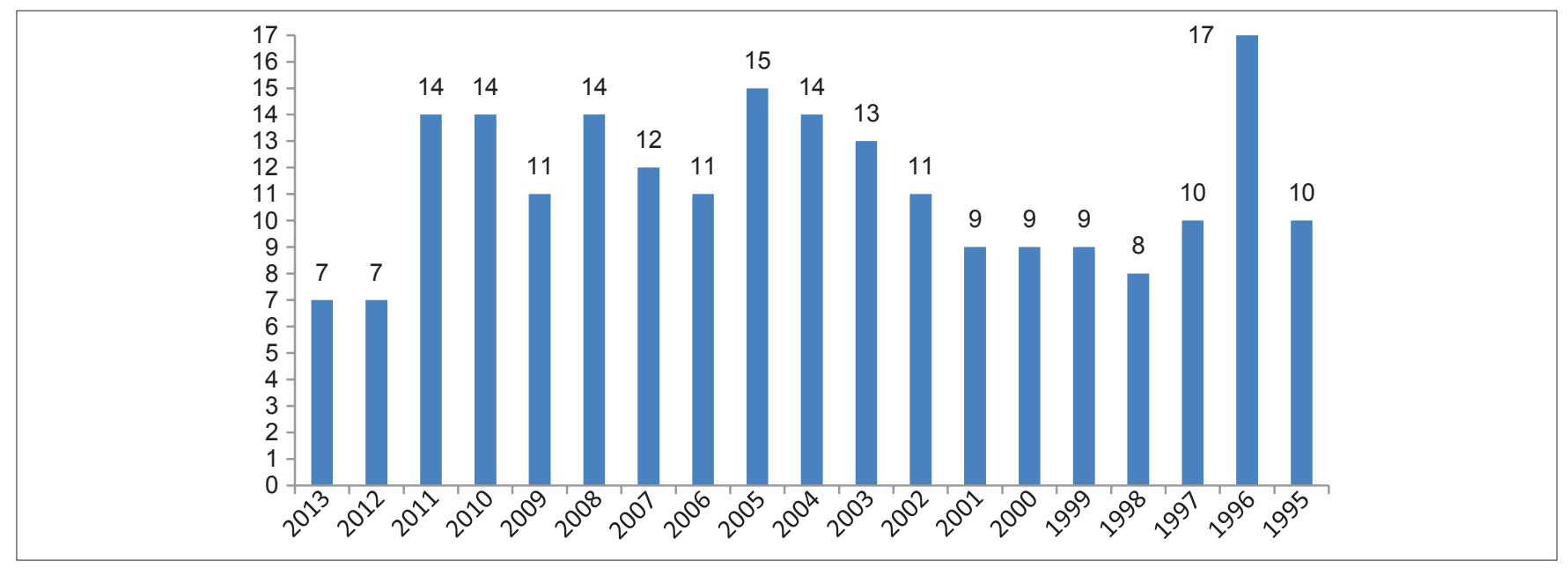

Figure 1: The number of publications between 1995 and 2013

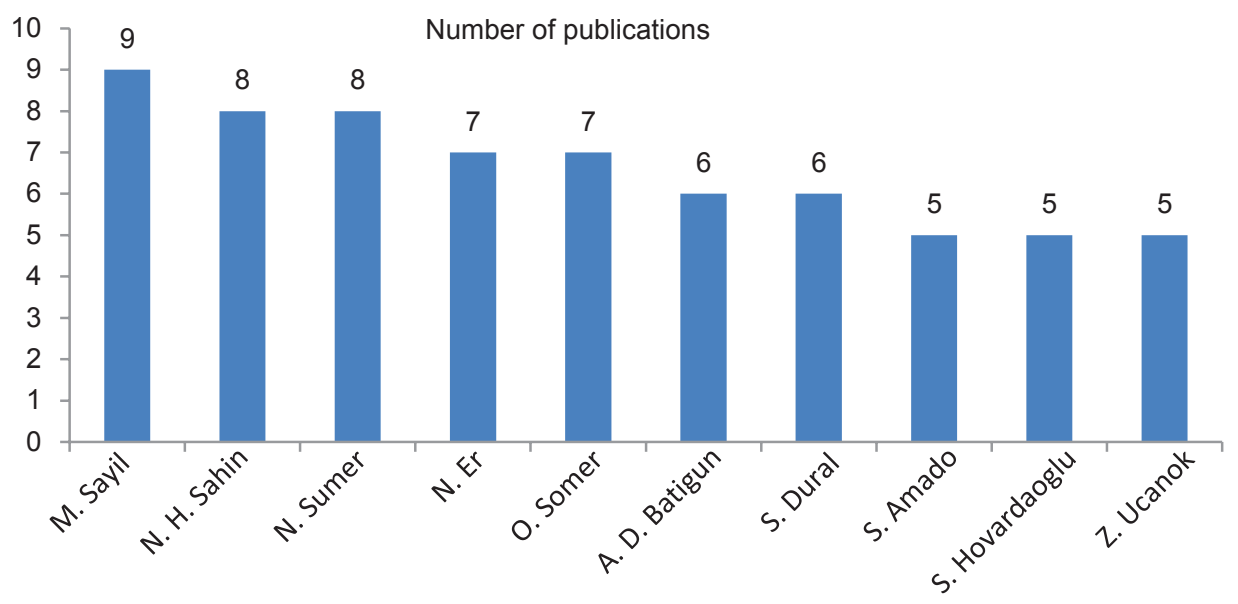

Figure 2: The ranking of authors who published most as a co-author 
publications were products of authors who were affiliated with universities in Ankara, such as Hacettepe, Ankara, and Orta Dogu Teknik (METU). Thus, this finding also shows that TPD remains a local journal, with contributions from local Turkish researchers. Figure 3 provides the affiliated universities, their languages of instruction, main campus locations, and the number of published authors.

\section{Full Title of the Scholarly Publications}

Social Science Citation Index provided 215 titles of TPD articles. Results showed that the total numbers of word types and word tokens were 912 and 2710, respectively, suggesting that on average a title had 4.24 different words and a total of 12.60 words. Figure 4 gives the 10 most common words and their occurrences in the titles.

Figure 5 provides another 10 most common words and their occurrences in the titles, omitting the six most frequent words according to English language corpora. The fact that "Turkish" was the most frequent word in the titles shows that being a local journal, articles published in TPD focused more on issues in psychology in Turkey than in any other region.

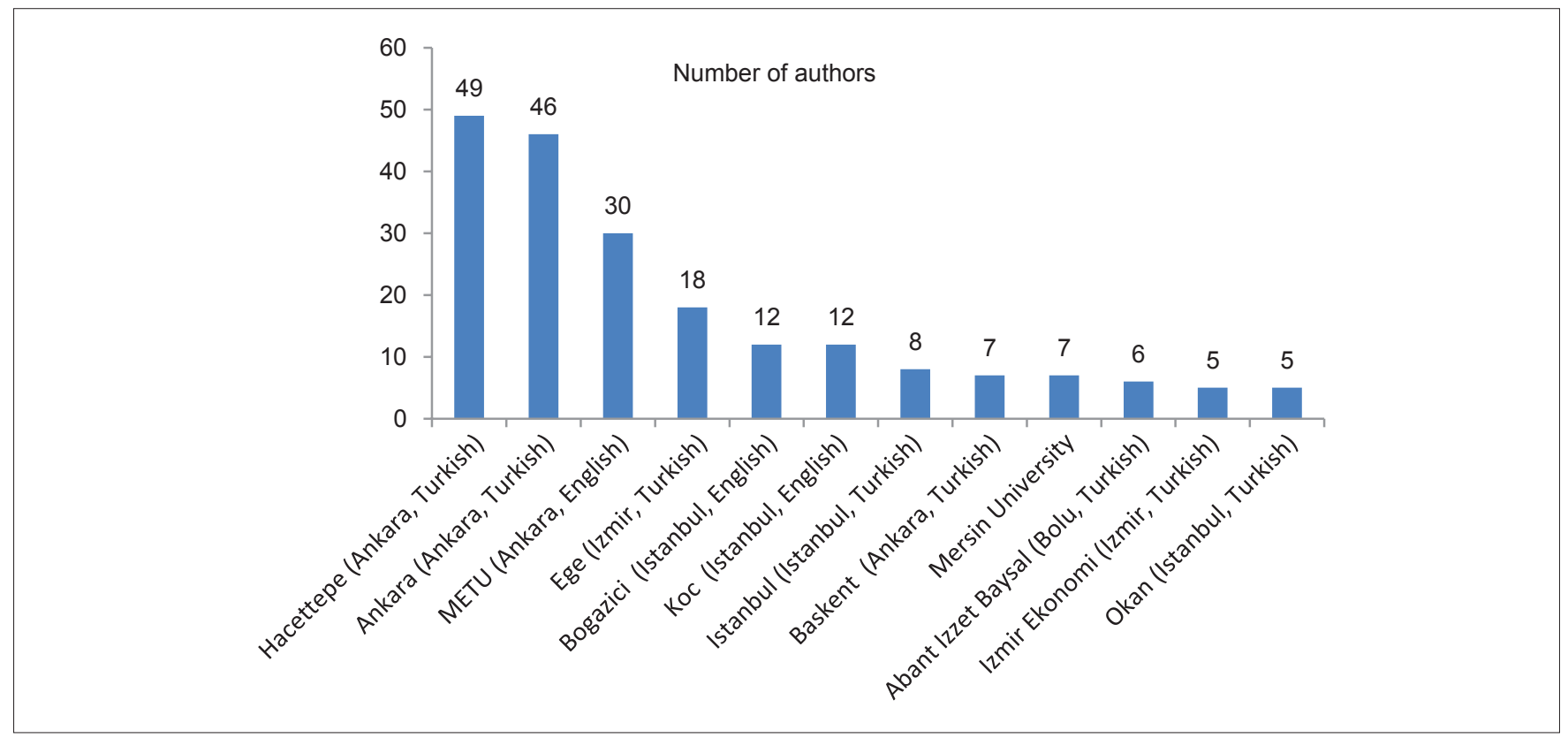

Figure 3: The Top Ten contributing universities

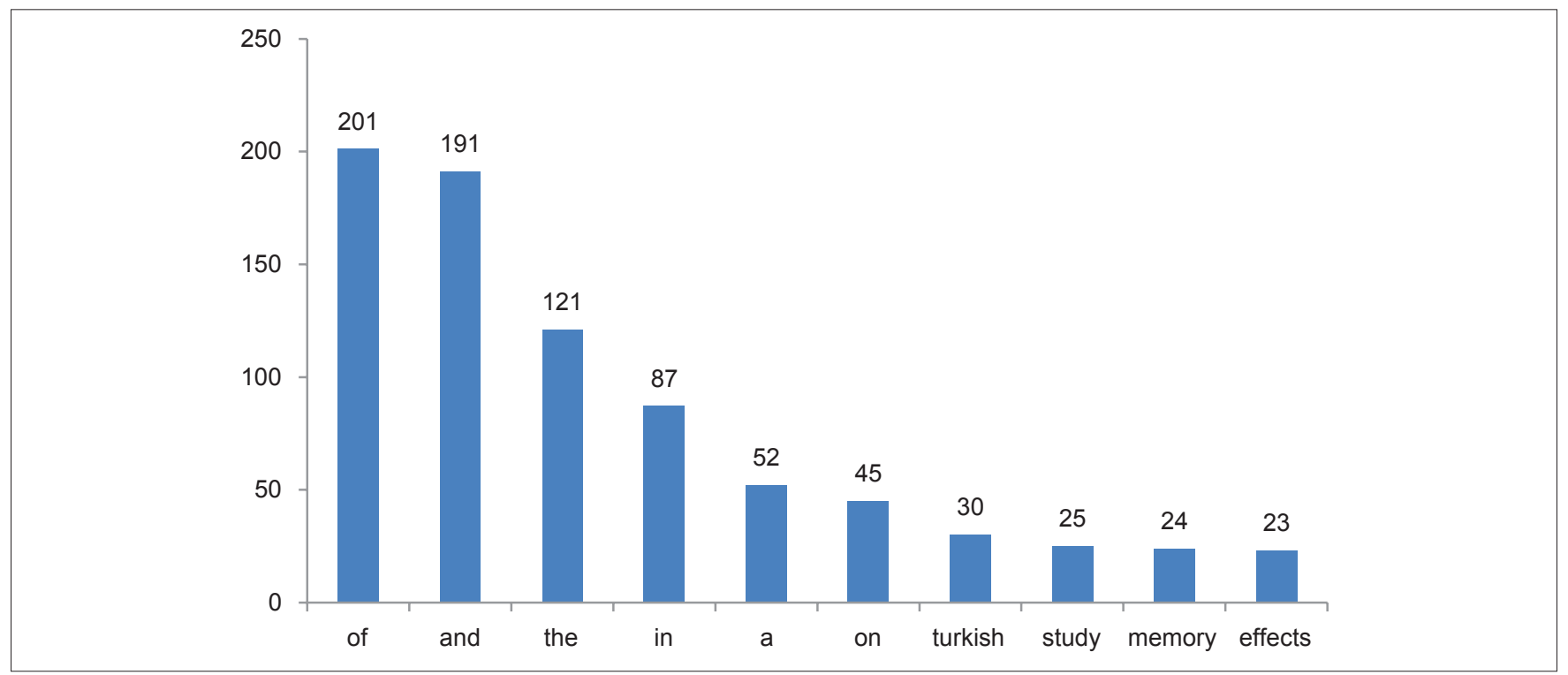

Figure 4: The 10 most common words and their occurrences in the titles of Turk Psikoloji Dergisi articles 


\section{Abstract}

There were a total of 213 abstracts from TPD accessible in SSCI. The total number of word types and tokens in the abstracts were 3802 and 38,197, respectively. An abstract had about 178 (178.40) words on average. The longest abstract was of Sahin, ${ }^{[2]}$ which had 336 words. The shortest abstract was of Ardah and Erten ${ }^{[23]}$ which had 38 words. Figure 6 gives the 10 most common words and their frequencies found in the abstracts. Omitting the most frequent words in any corpora of English, Figure 7 shows the 10 most common words in the TPD abstracts. The most frequent word in the abstracts was "study."
Considering voice in the abstracts, almost all of the sentences consisted of passive voice, such as "It was found..." or generic voice "The study showed..." Authors referred to themselves very rarely; the frequency of use of first-person singular "I" was 0 . The use of the third person singular "we" was 20, "us" was 1 , and generic "authors" were 3 , including 1 of which was a single authored publication.

As expected from literature in psychology, authors referred to people who took part of their studies as "participants" (127 times) and "subjects" (35 times), both of which are accepted by APA ${ }^{[24]}$. In terms of the year, the

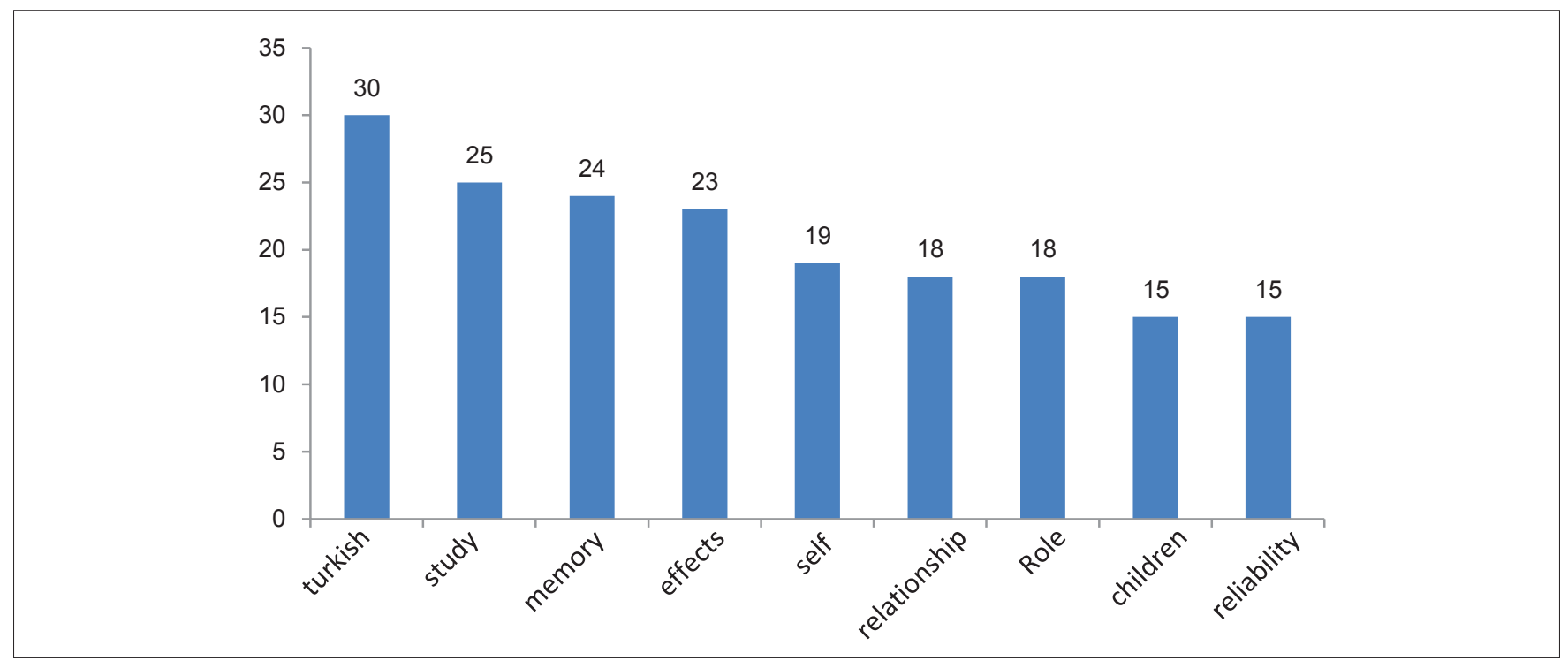

Figure 5: The most common words and their occurrences in the titles omitting the first six common words according to English corpora

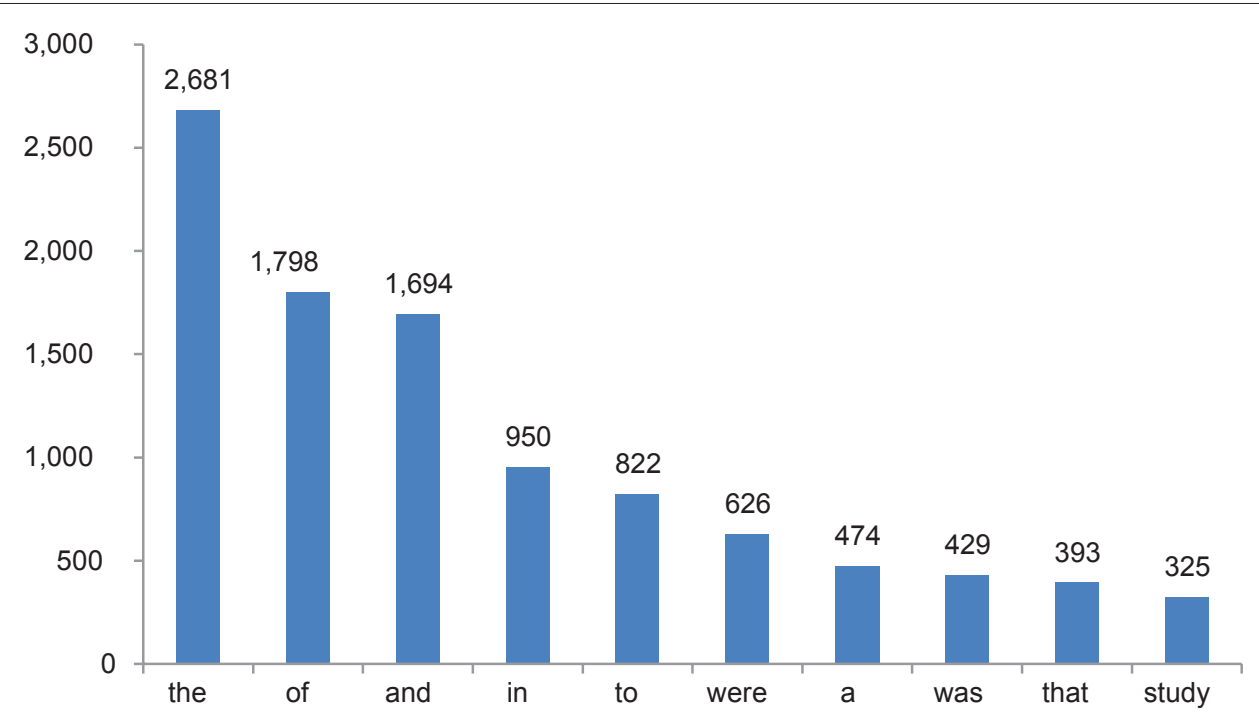

Figure 6: The 10 most common words and their frequencies found in the abstracts of Turk Psikoloji Dergisi articles 
earliest use of participants in an abstract was in Demir and Demir ${ }^{[25]}$ and the latest use of subjects was in Gulbetekin et al. ${ }^{[26]}$

In order to analyze the number of sentences in the TPD abstracts, I counted the number of periods "." in AntConc, and then removed them outside the sentence endings. However, there were several sentences without a period which I did not count. In total there were 1686 sentences, indicating that an abstract consisted of about 8 (7.91) sentences on average. Considering only the main clause of the sentences, which numbered 1686, about $19.86 \%$ of the sentences $(n=335)$ contained non-past tense; the rest contained past tense markers. Most of the non-past tense usage appeared in the first sentence of the abstract, e.g. "The aim of the study is..." or the last sentence of the abstract, e.g. "implications are discussed..." Yet, there were also many random tense shifts in the articles.

\section{Author Keywords}

There were 779 different author keywords in TPD. Articles had about 5 (4.69) keywords on average. Articles which had 5 keywords tended to have 3-4 (3.62) keywords that were different from any other article, suggesting that the articles concerned very diverse topics. Figure 8 represents the keywords that appeared more than 5 times among all keywords.

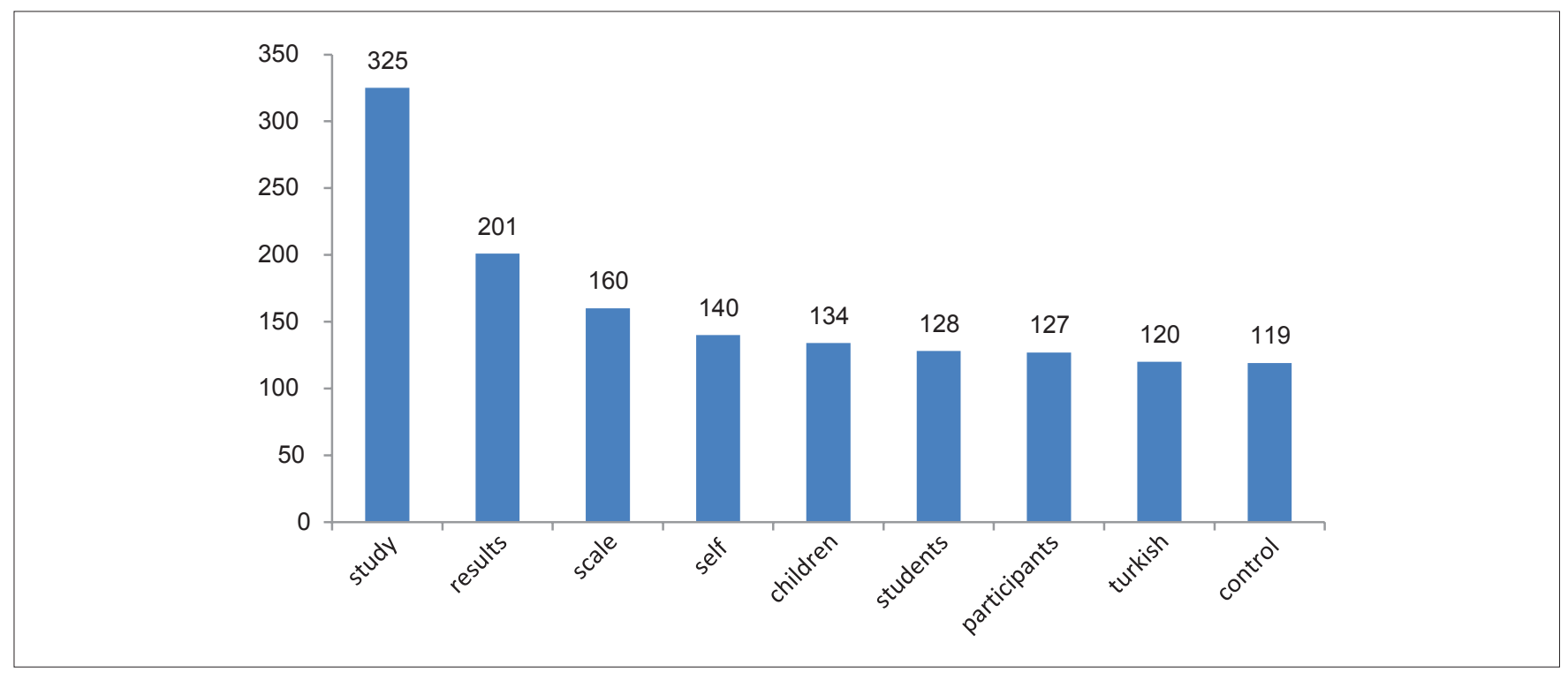

Figure 7: The most common words, omitting the common English words, and their frequencies found in the abstracts of Turk Psikoloji Dergisi articles

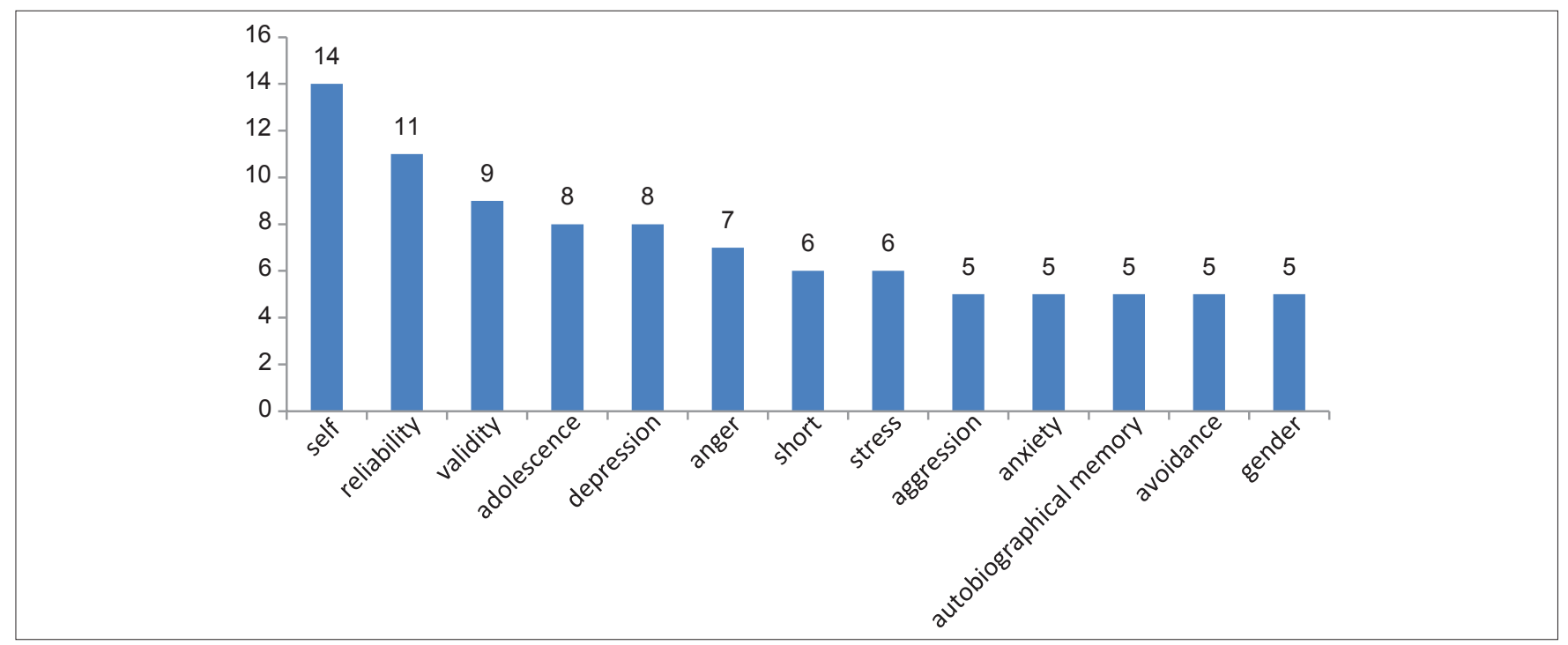

Figure 8: The ranking of most frequently used keywords in Turk Psikoloji Dergisi articles 


\section{KeyWords Plus}

There were 886 different words in KeyWords Plus in the TPD bibliometric data in SSCI. On average, each article had about 8 (7.52) keywords. Articles which had 8 keywords tended to have 4 (4.12) that were different from any other article. Figure 9 shows the keywords which appeared more than 10 times among all keywords used in TPD during this period.

\section{Citations}

Because articles in TPD received few citations, and the few they did receive were self-citations, its impact factor was relatively low. According to JCR, TPD was ranked 115 out of 126 journals in the category of Psychology, multidisciplinary with an impact factor of 0.214 in 2012. Comparatively, JCR listed Psychological Bulleting as having the highest impact factor (15.575) and Revista Latinoamericana de Psicopatologia Fundamental with the lowest (0.013). TPD's impact factor ranged between 0.076 and $0.278^{[16]}$ from 1995 to 2005, and between 0.056 and 0.263 from 2005 to 2013 [Table 1]. Its 5-year impact factor was 0.154 . In the following subsections, I analyze its citation patterns.

\section{Times Cited}

Articles in TPD were cited 702 times, indicating that on average, an article was cited 3.26 times. Out of the 215 articles, 95 did not receive any citations. Only 42 articles received citations above the average amount. The most cited article was Sumer and Gungor ${ }^{[19]}$ (59), followed by $\operatorname{Gencoz}^{[27]}$ (48); Eker and Arkar ${ }^{[28]}$ (36); Kostakoglu et al. ${ }^{[29]}$ (33); and Sahin and $\operatorname{Durak}^{[30]}$ (32).

A previous study ${ }^{[16]}$ found that of the 118 publications TPD published between 1995 and 2005, almost half of them did not receive any citations. Of the 135 which did, $35 \%$ were author self-citations and $41 \%$ were journal self-citations. Between 2005 and 2012, only 37 (38\%) of the 98 published articles were cited by another article indexed in SSCI or Arts and Humanities Citation Index, and the total number of citations was 87.34 (39\%) out of which 87 were author self-citations and 26 were journal self-citations.

Table 1: The impact factors of TPD in last 5 years

\begin{tabular}{lc}
\hline Year & Impact factor \\
\hline 2012 & 0.214 \\
2011 & 0.160 \\
2010 & 0.056 \\
2009 & 0.263 \\
2008 & 0.087 \\
\hline
\end{tabular}

TPD $=$ Turk Psikoloji Dergisi

Table 2: The articles cited more than 3 times published between 2005 and 2012

\begin{tabular}{lccc}
\hline Article & $\begin{array}{c}\text { Author } \\
\text { self-citation }\end{array}$ & $\begin{array}{c}\text { Journal } \\
\text { self-citation }\end{array}$ & $\begin{array}{c}\text { Total citations } \\
\text { in SSCl }\end{array}$ \\
\hline Yağmurlu et al..[32] & 4 & 2 & 8 \\
Sumer ${ }^{[31]}$ & 4 & 6 & 16 \\
Batigun and Utku' ${ }^{[33]}$ & 1 & 2 & 6 \\
Pekel-Uludagli and & 0 & 2 & 6 \\
Ucanok $^{[34]}$ & & 2 & 6 \\
Coşkunn $^{[35]}$ & 5 & & \\
\hline
\end{tabular}

SSCI: Social Science Citation Index

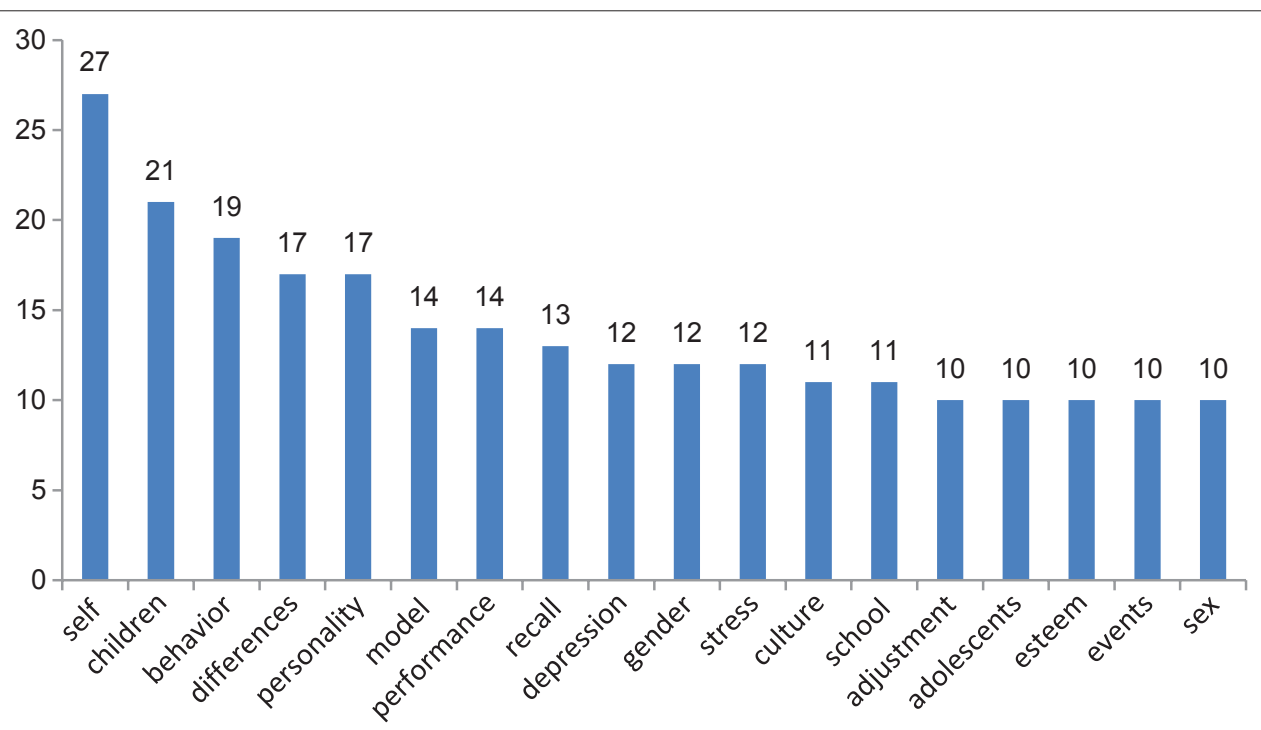

Figure 9: The ranking of mostly used keyword plus keywords in Turk Psikoloji Dergisi articles 
There were only five articles, which received more than three citations [Table 2]. Only one article ${ }^{[31]}$ was cited 16 times, including four author self-citations and six journal self-citations. Another article ${ }^{[32]}$ was cited eight times (four author self-citations and two journal self-citations). Batigun and Utku, ${ }^{[33]}$ Pekel-Uludagli and Ucanok ${ }^{[34]}$ and Coşkun ${ }^{[35]}$ received six citations each. The total number of the citations of these five articles was $42,48.27 \%$ of all citations within the last 5 years.

A closer examination reveals the author self-citation patterns [Table 3]. Author self-citations occurred in journals mostly of Turkish origin: 14 articles in TPD, 3 articles in the Turkish Journal of Psychiatry, 1 article in Kuram ve Uygulamada Egitim Bilimleri and 1 article in Egitim and Bilim. Of these journals, the Journal of Mathematical Psychology had the highest impact factor (1.622).

An analysis of citations excluding author self-citations revealed that, again, these citations were mostly received from journals of Turkish origin: TPD (16 times), the Turkish Journal of Psychiatry (1 time), Kuram ve Uygulamada Egitim Bilimleri (8 times), Egitim ve Bilim (1 time), Egitim Arastirmalari (2 times), Noropsikiyatri Arsivi (1 time), Anadolu Psikiyatri Dergisi (1 time), Hacettepe Universitesi Egitim Fakultesi Dergisi (1 time), and Iktisat Isletme ve Finans (1 time) [Table 4]. Of these journals, developmental review had the highest impact factor (3.452). The fact that these author self-citations occurred mostly in journals

Table 3: The journals in which TPD authors cited themselves between 2005 and 2012

\begin{tabular}{lcc}
\hline Journal & $\begin{array}{c}\text { No. of } \\
\text { author } \\
\text { self-citations }\end{array}$ & $\begin{array}{c}\text { Impact } \\
\text { factor } \\
\text { in 2012 }\end{array}$ \\
\hline $\begin{array}{l}\text { Applied Psychology-An International } \\
\text { Review-Psychologie Appliquee-Revue }\end{array}$ & 1 & 1.533 \\
Internationale & 1 & 0.429 \\
Egitim ve Bilim-Education and Science & 2 & 0.867 \\
Infant and Child Development & 1 & 1.591 \\
International Journal of Behavioral & 3 & 1.422 \\
Development & 2 & 0.594 \\
Journal of Child and Family Studies & 1 & 1.622 \\
Journal of Creative Behavior & 1 & 0.804 \\
Journal of Mathematical Psychology & 1 & 1.131 \\
Journal of Psychology & 1 & 0.316 \\
Journal of Social and Personal Relationships & 1 & - \\
Kuram ve Uygulamada Egitim Bilimleri & 1 & 0.382 \\
Procedia Social and Behavioral Sciences & 3 & 0.615 \\
Revista Latinoamericana de Psicologia & 14 & 0.214 \\
Turk Psikiyatri Dergisi & &
\end{tabular}

TPD $=$ Turk Psikoloji Dergisi from Turkey provides yet another indication of TPD's locality.

\section{Cited References}

Articles in TPD cited a total of 9843 sources, with each article citing 46 (45.78) sources on average. The three articles citing the most sources were Sahin et al. ${ }^{[36]}$ (110); Nacak et al. ${ }^{[37]}$ (101) sources; and Batigun ${ }^{[38]}$ (101). The three articles citing the least sources were Kaplama and $\operatorname{Varoglu}^{[39]}$ (4); Uluc ${ }^{[40]}$ (3); and Sumer ${ }^{[20]}$ (3). The most cited authors (as first authors) and articles are given in Figure 10 and Table 5. Interestingly, the majority of these cited authors and articles were of Turkish origin, indicating that TPD stands as a local journal in cited references.

Table 4: The journals citing the TPD articles published between 2005 and 2013

\begin{tabular}{|c|c|c|}
\hline Name of the journal & $\begin{array}{l}\text { Number of } \\
\text { citations }\end{array}$ & $\begin{array}{l}\text { Impact factor } \\
\text { in } 2012\end{array}$ \\
\hline $\begin{array}{l}\text { Anadolu Psikiyatri Dergisi-Anatolian } \\
\text { Journal of Psychiatry }\end{array}$ & 1 & 0.184 \\
\hline $\begin{array}{l}\text { Australian Journal of Guidance and } \\
\text { Counselling }\end{array}$ & 1 & 1.152 \\
\hline Clinical Linguistic s and Phonetics & 1 & 0.783 \\
\hline Contemporary Nurse & 1 & 0.439 \\
\hline $\begin{array}{l}\text { Cyberpsychology Behavior and Social } \\
\text { Networking }\end{array}$ & 1 & 1.842 \\
\hline Developmental Review & 1 & 3.452 \\
\hline $\begin{array}{l}\text { Egitim Arastirmalari-Eurasian Journal } \\
\text { of Educational Research }\end{array}$ & 2 & 0.455 \\
\hline Egitim ve Bilim-Education and Science & 1 & 0.429 \\
\hline European Journal of Pediatrics & 1 & 1.907 \\
\hline $\begin{array}{l}\text { Group Processes and Intergroup } \\
\text { Relations }\end{array}$ & 1 & 1.528 \\
\hline $\begin{array}{l}\text { Hacettepe Universitesi Egitim } \\
\text { Fakultesi Dergisi-Hacettepe University } \\
\text { Journal of Education }\end{array}$ & 1 & 0.350 \\
\hline Iktisat Isletme ve Finans & 1 & 0.278 \\
\hline $\begin{array}{l}\text { International Journal of Intercultural } \\
\text { Relations }\end{array}$ & 1 & 0.940 \\
\hline Journal of Adolescence & 1 & 1.882 \\
\hline Journal of Hydrologic Engineering & 2 & 1.379 \\
\hline Kuram ve Uygulamada Egitim Bilimleri & 8 & 0.316 \\
\hline $\begin{array}{l}\text { Noropsikiyatri Arsivi-Archives of } \\
\text { Neuropsychiatry }\end{array}$ & 1 & 0.221 \\
\hline $\begin{array}{l}\text { Procedia Social and Behavioral } \\
\text { Sciences }\end{array}$ & 4 & - \\
\hline $\begin{array}{l}\text { Proceedings of the Institution of Civil } \\
\text { Engineers-Water Management }\end{array}$ & 1 & 0.536 \\
\hline Safety Science & 1 & 1.359 \\
\hline Sprache-Stimme-Gehor & 1 & 0.104 \\
\hline Thinking Skills and Creativity & 1 & 1.033 \\
\hline $\begin{array}{l}\text { Turk Psikiyatri Dergisi-Turkish Journal } \\
\text { of Psychiatry }\end{array}$ & 1 & 0.615 \\
\hline TPD & 16 & 0.214 \\
\hline
\end{tabular}

TPD $=$ Turk Psikoloji Dergisi 


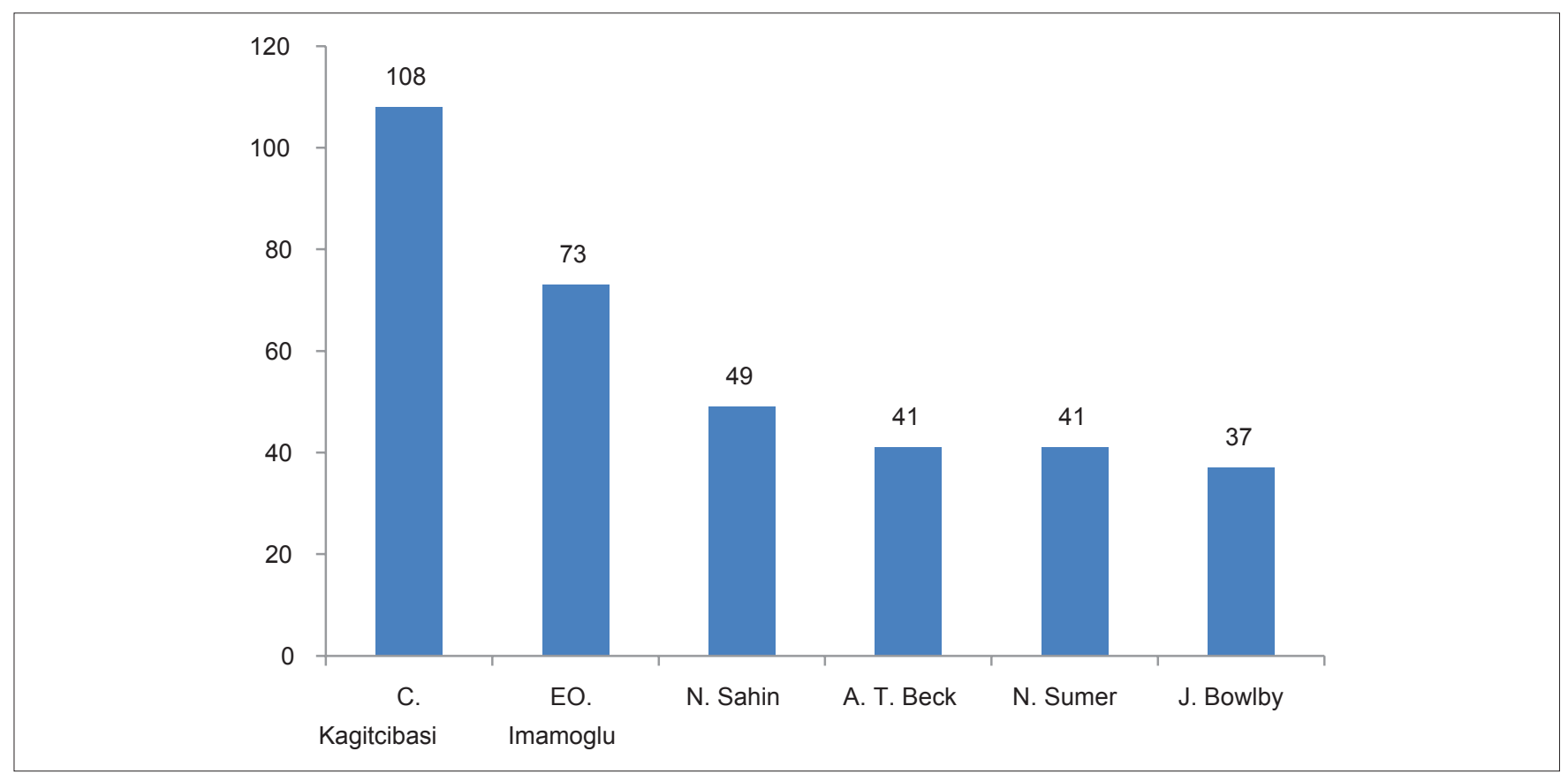

Figure 10: The ranking of the most cited authors in Turk Psikoloji Dergisi articles

Table 5: The ranking of the most cited publications in TPD articles

\begin{tabular}{|c|c|}
\hline Name & No. of citations \\
\hline Hisli[i[1] in TPD & 12 \\
\hline $\begin{array}{l}\text { Baron and Kenny }{ }^{[42]} \text { in Journal of Personality and } \\
\text { Social Psychology }\end{array}$ & 11 \\
\hline Sumer and Gungor ${ }^{[19]}$ in TPD & 8 \\
\hline Sahin and Durak ${ }^{[43]}$ TPD & 8 \\
\hline Markus and Kitayama ${ }^{[44]}$ in Psychological Review & 8 \\
\hline Imamoglu ${ }^{[18]}$ in Journal of Psychology & 8 \\
\hline $\begin{array}{l}\text { Goregenli[i[5] in Journal of Cross-Cultural } \\
\text { Psychology }\end{array}$ & 8 \\
\hline
\end{tabular}

\section{CONCLUSION}

In this study, I have investigated the main bibliometric characteristics of a local/national journal, TPD, one of the leading journals in Turkey indexed in SSCI's Multidisciplinary Psychology section. The journal is highly respectable in Turkey because it is one of the fourteen journals, and the only psychology journal from Turkey, indexed in SSCI. The results showed that in spite of its reputation, TPD remains extremely local without a clear focus indicating that it does not carry characteristics of high impact journals in the field. ${ }^{[4]}$

This locality was observed in almost all domains of bibliometric data from SSCI. TPD's scientific and advisory board consisted of only local researchers, similar to what was found in that of other Turkish journals indexed in SSCI. ${ }^{[4]}$ It has published articles mostly (84.65\%) in Turkish despite the fact that English is becoming the international language of science. ${ }^{[48]}$ The articles have been authored by a group of, almost all, Turkish researchers with few collaborations (2 authors per article), contrary to the general increase in international collaborations in scientific publications. ${ }^{[12]}$ These findings echo what was observed by Gulgoz et al. ${ }^{[13]}$ and Gossart and Ozman ${ }^{[15]}$ regarding the limited nature of scientific networks in Turkey. The findings also indicate very little contribution of Turkish publications to psychology internationally.

Furthermore, TPD has a very low 5-year impact factor due to its citation patterns (0.154). In the last 7 years, only $38 \%$ of all articles were cited by another article, and among these 39\% were author self-citations and 30\% were journal self-citations. These impact factor and citation patterns seem to have stagnated over the years and are similar to the observations on TPD made earlier by $\mathrm{Al}$ and Costur. ${ }^{[16]}$ It appears that most of the highly cited references were authored by local researchers, even though there was not a single Turkish researcher listed among highly eminent psychologists by Simonton ${ }^{[49]}$ and Haggbloom et al. ${ }^{[50]}$ TPD contained articles focusing on very diverse topics from self to culture, memory to depression to scale development. This was indicated by highly diverse keywords: (3.62) Keywords unique to an article on average. The titles also reflected that TPD is a local journal because, other than common words such as the, in, and of, the most frequently used the word in the titles was "Turkish." The findings also indicate little impact of Turkish publications to psychology internationally. 
Going back to the main questions of this study, the findings from the current study suggest that national journals can survive by remaining extremely national without attempting to become international as apparent in many domains of bibliometric data from WoS. TPD has been included in SSCI since 1995, but the data have shown that its bibliometric characteristics have not changed much. Its advisory board consists of only Turkish scholars if the journals aim at becoming an international journal one might expect to see board members from various countries. TPD does not change its publication frequency. It publishes only two issues per year even though there is an increase in the number of publications (inter) nationally in WoS. One could expect to see articles mainly written in English to reach an international audience, but TPD does not do that. Most of its articles are in Turkish. Similarly, almost of all of the authors reside in Turkey mainly from several Turkish universities but not all. The articles in TPD cite Turkish studies more than internationally highly cited studies and they receive few citations mainly self-citations or citations from other national journals. It publishes articles from all domains of psychological studies focusing on Turkish population. Yet, an international journal would do otherwise. Overall, the data on TPD suggest that national journals stay local from their editors to the topics they covered and from their publication frequency to citation patterns even if they are covered in WoS. Future research will investigate other national journals to further test these predictions.

\section{REFERENCES}

1. Lawrence PA. Rank injustice. Nature 2002;415:835-6.

2. Lawrence PA. The politics of publication. Nature 2003;422:259-61.

3. Lawrence PA. Lost in publication: how measurement harms science? Ethics Sci Environ Polit 2008;8:9-11.

4. Reich ES. Science publishing: The golden club. Nature 2013;502:291-3.

5. Owens B. Research assessments: Judgement day. Nature 2013;502:288-90.

6. Asan H. Impact factor: An analysis of 4 Turkish SCI-Expanded journals with an impact factor above 1. In: Yılmaz O, ed. Journal Publications in Health Sciences 2011. 9th National Symposium. Ankara: Aves; 2011. p. 66-78.

7. Russ-Eft D. SSCI, ISI, JCR, JIF, IF, and journal quality. Hum Resour Dev Q 2008;19:185-9.

8. Nederhof AJ, van Leeuwen TN, van Raan AF. Highly cited non-journal publications in political science, economics and psychology: a first exploration. Scientometrics 2010;83:363-74.

9. Lluch JO. Some considerations on the use of the impact factor of scientific journals as a tool to evaluate research in psychology. Scientometrics 2005;65:189-97.

10. Arik E. Turkey's Output in Psychological Publications: An Overview of Web of Knowledge between 1980 and 2013. Elestirel Psikoloji Bulteni 2014;5:81-96.
11. Guilera G, Barrios M, Gomez-Benito J. Meta-analysis in psychology: a bibliometric study. Scientometrics 2013;94:943-54.

12. Kliegl $R$, Bates $D$. International collaboration in psychology is on the rise. Scientometrics 2011;87:149-58.

13. Gulgoz S, Yedekcioglu OA, Yurtsever E. Turkey's output in social science publications: 1970-1999. Scientometrics 2002;55:103-21.

14. Tonta Y, İlhan M. Turkey's place in social science publications in the world. Türk Psikoloji Dergisi 1997;12:67-75.

15. Gossart C, Ozman M. Co-authorship networks in social sciences: The case of Turkey. Scientometrics 2009;78:323-45.

16. AIU, Costur R. Bibliometric Profile of Turkish Journal of Psychology. Turkish Librarianship 2007;21:142-63.

17. Anthony L. AntConc (Version 3.2.4) [Computer Software]. Tokyo, Japan: Waseda University; 2011. Available from: http://www.antlab. sci.waseda.ac.jp/On 01-05-2013.

18. Imamoglu EO. Individualism and collectivism in a model and scale of balanced differentiation and integration. J Psychol 1998;132:95-105.

19. Sumer N, Gungor D. Psychometric evaluation of adult attachment measures on Turkish samples and a cross-cultural comparison. Turk Psikoloji Dergisi 1999;14:71-109.

20. Sumer C. Ethical principles of psychological practice, research and publications in Turkey: Discussion I. Turk Psikoloji Dergisi 1998;13:77-9.

21. Backs BJ, Dobson KS. Cognitive therapy for depression: Conceptual and empirical issues. Turk Psikoloji Dergisi 1998;13:47-76.

22. Sahin DN. The effect of effort/ability based contributions and equal/ equitable allocations on the perceived fairness of positive and negative outcomes. Turk Psikoloji Dergisi 2003;18:17-31.

23. Ardah C, Erten Y. Short-term psychotherapies. Turk Psikoloji Dergisi 1996;11:53-61.

24. American Psychological Association. Publication Manual of the American Psychological Association. $6^{\text {th }}$ ed. Washington, DC; 2010.

25. Demir G, Demir A. Assessment of psychological symptoms of prisoners. Turk Psikoloji Dergisi 1998;13:35-46.

26. Gulbetekin E, Iyilikci O, Amado S, Cetinkaya H, Dura S. Hemispheric asymmetry in expression and perception of happiness. Turk Psikoloji Dergisi 2012;27:65-83.

27. Gencoz T. Positive and negative affect schedule: A study of validity and reliability. Turk Psikoloji Dergisi 2000;15:19-28.

28. Eker $\mathrm{D}$, Arkar $\mathrm{H}$. Factorial structure, validity, and reliability of the multidimensional scale of perceived social support. Turk Psikoloji Dergisi 1995;10:45-55.

29. Kostakoglu E, Batur S, Tiryaki A, Gogus A. Reliability and validity of the Turkish version of the positive and negative syndrome scale (PANSS). Turk Psikoloji Dergisi 1999;14:23-34.

30. Sahin NH, Durak A. A brief coping styles inventory for university-students. Turk Psikoloji Dergisi 1995;10:56-73.

31. Sumer N. Categorical and dimensional comparison of the adult attachment measures. Turk Psikoloji Dergisi 2006;21:1-24.

32. Yağmurlu B, Çıtlak B, Dost A, Leyendecker B. Child socialization goals of Turkish mothers: An investigation of education related within-culture variation. Turk Psikoloji Dergisi 2009;24:1-19.

33. Batigun $A D$, Utku C. A study on the relationship between eating attitudes and anger. Turk Psikoloji Dergisi 2006;21:65-82.

34. Pekel-Uludagli N, Ucanok Z. Loneliness, academic achievement and types of bullying behavior according to sociometric status inbully/victim groups. Turk Psikoloji Dergisi 2005;20:77-95.

35. Coşkun $\mathrm{H}$. The effect of divergent thinking and group composition on idea generation in brainwriting. Turk Psikoloji Dergisi 2005;20:25-42.

36. Sahin NH, Basim HN, Akkoyun N. Three critical components in the Type-A and stress relationship: Anger, ineffective coping, and obsession with work. Turk Psikoloji Dergisi 2011;26:31-51. 
37. Nacak M, Yagmurlu B, Durgel E, van de Vijver F. Parenting in metropole and anatolia samples: The role of residence and education in beliefs and behaviors. Turk Psikoloji Dergisi 2011;26:85-104.

38. Batigun AD. Suicide risk and gender: An evaluation of suicide in respect to interpersonal relationship style, reasons for living, loneliness, and hopelessness. Turk Psikoloji Dergisi 2008;23:65-78.

39. Kaplama V, Varoglu AK. "Learning to learn" as a tool of total quality management (TQM) in educational institutions. Turk Psikoloji Dergisi 1997;12:81-97.

40. Uluc S. A quick device for moel therapy. Turk Psikoloji Dergisi 2005;20:127-30.

41. Hisli N. Beck depresyon envanterinin geçerliği üzerine bir çalışma. Turk Psikoloji Dergisi 1989;22:118-26.

42. Baron RM, Kenny DA. The moderator-mediator variable distinction in social psychological research: Conceptual, strategic, and statistical considerations. J Pers Soc Psychol 1986;51:1173-82.

43. Sahin NH, Durak A. Kısa Semptom Envanteri: Türk Gençleri için uyarlanması. Turk Psikoloji Dergisi 1994;31:44-56.

44. Markus H, Kitayama S. Culture and the self: Implications for cognition, emotion, and motivation. Psychol Rev 1991;98:224-53.
45. Goregenli M. The individualistic-collectivist tendencies in a Turkish sample. J Cross-Cult Psychol 1997;28:787-94.

46. Walters GD. The citation life cycle of articles published in 13 American psychological association journals: A25-year longitudinal analysis. J Am Soc Inf Sci Technol 2011;62:1629-36.

47. Al U, Soydal İ. Atıf dizinlerindeki Türkiye adresli dergiler üzerine bir değerlendirme. Bilgi Dunyasi 2012;12:13-29.

48. Engber D. FYI: How did English get to be the international language of science? Popular Science, 2013, Nov 06.

49. Simonton DK. Methodological and theoretical orientation and the long-term disciplinary impact of 54 eminent psychologists. Rev Gen Psychol 2000;4:13-24.

50. Haggbloom SJ, Warnick SR, Warnick JE, et al. The 100 most eminent psychologists of the $20^{\text {th }}$ Century. Rev Gen Psychol 2002;6:139-52.

How to cite this article: Arik E. A bibliometric analysis of a national Journal: The case of the Turkish Journal of Psychology. J Sci Res 2013;2:173-84.

Source of Support: Nil, Conflict of Interest: None declared

\section{Author Help: Online submission of the manuscripts}

Articles can be submitted online from http://www.journalonweb.com. For online submission, the articles should be prepared in two files (first page file and article file). Images should be submitted separately.

\section{1) First Page File:}

Prepare the title page, covering letter, acknowledgement etc. using a word processor program. All information related to your identity should be included here. Use text/rtt/doc/pdf files. Do not zip the files.

\section{2) Article File:}

The main text of the article, beginning with the Abstract to References (including tables) should be in this file. Do not include any information (such as acknowledgement, your names in page headers etc.) in this file. Use text/rtt/doc/pdf files. Do not zip the files. Limit the file size to $1 \mathrm{MB}$. Do not incorporate images in the file. If file size is large, graphs can be submitted separately as images, without their being incorporated in the article file. This will reduce the size of the file.

3) Images:

Submit good quality color images. Each image should be less than $4096 \mathrm{~kb}(4 \mathrm{MB})$ in size. The size of the image can be reduced by decreasing the actual height and width of the images (keep up to about 6 inches and up to about $1800 \times 1200$ pixels). JPEG is the most suitable file format. The image quality should be good enough to judge the scientific value of the image. For the purpose of printing, always retain a good quality, high resolution image. This high resolution image should be sent to the editorial office at the time of sending a revised article.

4) Legends:

Legends for the figures/images should be included at the end of the article file. 